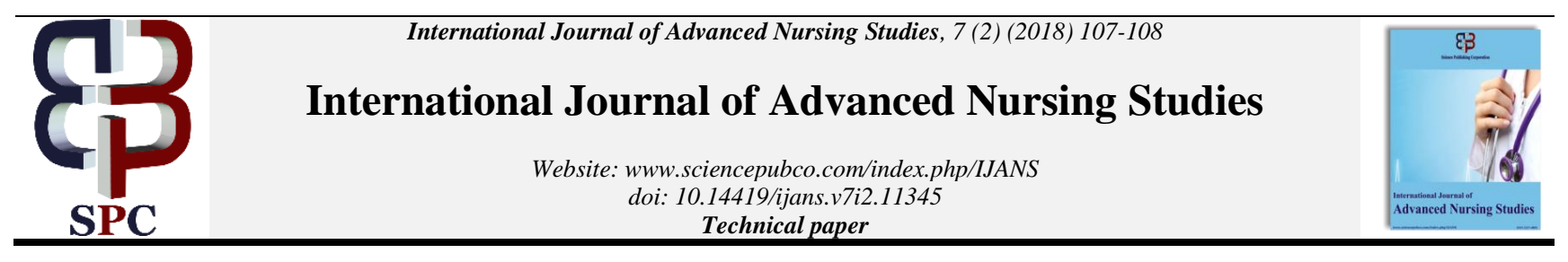

\title{
Coping skill training and family health education against anxiety in prevention substance abuse in Indonesia
}

\author{
Nita Sukamti ${ }^{1}$, Budi Anna Keliat ${ }^{1}$, Mustikasari ${ }^{2}$ \\ ${ }^{1}$ Postgraduate Programmed Faculty of Nursing, Universitas Indonesia, Depok, West Java -16424 \\ ${ }^{2}$ Faculty of Nursing, Universitas Indonesia \\ *Corresponding author_E-mail: budianna_keliat@yahoo.com
}

\begin{abstract}
Adolescents are vulnerable to get anxiety and it can affect to substance use. Coping skill training and family health education are mental nursing intervention that is expected to overcome anxiety. The goals of the research to determine the influence of coping skill training and family health education against anxiety in Junior High School. The research design is quasi-experimental pre-posttest with control group and 87 students in Junior High School was chosen by using purposive sampling technique then continued with cluster random sampling. Respondents were divided into 2 groups. Group 1 get nursing intervention and group 2 get nursing intervention, coping skills training, and family health education. The results showed decrease of anxiety that not significant after nursing intervention ( $\mathrm{p}$ value $>0.05$ ), and significantly decrease of anxiety after the coping skill training and family health education ( $\mathrm{p}$ value $<0,05)$. Coping skill training and family health education is recommended to decrease anxiety in adolescent.
\end{abstract}

Keywords: Adolescent; Substance; Anxiety; Coping Skill; Health Education

\section{Introduction}

\section{Background}

Adolescence is the transition from childhood to adulthood. Adolescent often try new things one of them using substances or drugs. Beginning with nicotine contained in cigarettes, then increased to the use of alcohol and marijuana. There is a further possibility that adolescent will use more serious drugs (9). Use of drugs includes abuse and dependence of drugs (14).

Based on United Nations Office on Drugs and Crime report ${ }^{(10)}$, the number of drug users globally in 2014 reached about 247 million people. Based on survey of the National Narcotics Agency with Health Research Center of University of Indonesia in 2015, the prevalence of addicts and drug abusers is $2.2 \%$ and found an enhancement in drug use in adolescents.

Emotional conditions of an individual such as depression, fear, anxiety and even to overcome the boredom and fatigue, triggering the individual to use drugs (9). Substance use is also associated with anxiety disorders in the transition from adolescence to adulthood (12). Anxiety and stress in adolescents are usually associated with relationships between adolescents and families, adolescent and peer relationships and adolescent and couple (4).

Substance abuse can not be separated from adolescent's resilience on negative things that happened. Resilience is a good action when faced with difficulties so it help the individual to withstand the negative effects of their difficulties ${ }^{(5)}$. Resilience is one part of individual coping. Based on research result, coping is very useful for clients who have anxiety (1).

Parental participation in adolescent supervision is also an important factor in the prevention of substance abuse. Less supervision of parents cause adolescent to use alcohol, tobacco and other substances earlier (7). Restrictions on playing time outside and close relationships between adolescents with families who have good compassion and religion are the protective factors of drug abuse (3).

Providing of health education to the family becomes another effort to overcome anxiety. Health education is a combination of learning experiences designed to help individuals or groups improve their health by increasing their knowledge or influencing their behavior (11).

The goals of the study to determine anxiety changes in adolescents as an effort to prevent drug abuse in junior high school.

\section{Method}

This research used quasi experimental with pre and post with control group. Group 1 got Nursing Intervention (NI) and Group 2 got Nursing Intervention (NI), Coping Skill Training (CST) and Family Health Education (FHE). This study was conducted in junior high school adolescents in Indonesia.

Researchers protect adolescent's rights. Before research was conducted, researcher gave a sheet of information about the research and the risks that may be faced by adolescents. Adolescents took part the study voluntarily without coercion and then fill out the approval sheet provided by the researcher.

\section{Result}

A total of 87 junior high school students aged 13-15 years became respondents in this study. The amount of female are 69 and male are 18 . After examination, $51.2 \%$ of parents applied permissive parenting. 
The results of this study showed that there was influence of coping skills training and family health education toward adolescent anxiety.

Based on table 1 it can be seen that after the nursing intervention, anxiety decrease from 12.41 to 10.93 . According to Hamilton Anxiety Rating Scale adolescent anxiety is included in the category of mild anxiety (score $=1-17$ ). After the self training, anxiety decreased to 10.41 and included in the mild anxiety category (score $=$ 1-17). Thus, the test results showed that there was a significant decrease in anxiety before and after the nursing intervention ( $\mathrm{p}$ value $<0.05)$.
Based on table 2 it can be seen that there is decrease of anxiety mean in the group before nursing intervention and after nursing intervention from 10.83 to 11.27 . Decrease of anxiety mean was also seen after the respondents got coping skill training and family health education become 9.93. According to Hamilton Anxiety Rating Scale, adolescent anxiety is included in the category of mild anxiety (score $=1-17$ ). The test results showed that there was an anxiety level difference before nursing intervention and after nursing intervention, coping skill training, and family health education ( $\mathrm{p}$ value $<0,05$ ).

Table 1: The Influence of NI against Anxiety in Group $1(\mathrm{~N}=46)$

\begin{tabular}{lllll}
\hline Variable & $\mathrm{n}$ & $\begin{array}{l}\text { Mean Before } \\
\text { NI }\end{array}$ & Mean After NI & Mean After Self-training \\
\hline Anxiety & 46 & 12,41 & 10,93 & 10,41 \\
\hline
\end{tabular}

Table 2: The Influence of NI, CST and FHE against Anxiety in Group $2(\mathrm{~N}=41)$

\begin{tabular}{llllll}
\hline Variable & $\mathrm{n}$ & Mean Before NI & Mean After NI & Mean After NI, CST, FHE & P Value \\
\hline Anxiety & 41 & 10,83 & 11,27 & 9,93 & 0,004 \\
\hline
\end{tabular}

Table 3: Mean Difference of Anxiety ( $\mathrm{N}=87)$

\begin{tabular}{llll}
\hline Variable & Group & Mean Diff & P value \\
\hline \multirow{2}{*}{ Anxiety } & Group 1 & $-1,95$ & 0,880 \\
& Group 2 & $-0,90$ & \multirow{2}{*}{0,80} \\
\hline
\end{tabular}

\section{Discussion}

Mean level of anxiety in adolescents is mild anxiety. Most adolescent state that school conditions can be a trigger for adolescents to get anxiety. The condition of adolescents in subject's examination and the method of teachers in teaching causes anxiety symptoms in adolescents. In addition, friendship with the opposite sex also often makes adolescent feel anxiety.

After the evaluation, adolescent feel more comfortable and relax after deep breathing exercises. When do a deep breath, individual sipping more oxygen and reducing carbon dioxide. Fresh air enters the brain and renews brain cells so that the blood supply and circulation become optimal. Repeating exercises will make it easier for individuals to concentrate, control emotions, and relax muscles. (8) In the practice of coping skills training, adolescents are taught various ways to improve their self-defense when feeling anxiety. The results showed that muscle-stretching exercises were effective in reducing stress and anxiety in schizophrenic patients (13). Muscle tension due to anxiety can be made more relax then anxiety can be reduced (9). This suggests that muscle relaxing exercises are effective to overcome anxiety.

Family health education is given as another effort to overcome anxiety. Parental support is very important for adolescent as they face new challenges or face situations that suppress their abilities ${ }^{(6)}$.

\section{Conclusion}

There is influence of coping skills training and family health education to anxiety ( $\mathrm{p}$ value $<0,05$ ).

The researcher's suggestion for subsequent research is to do the same research with more attention to equality on research variables. The number of male and female respondents is balanced in order it can be known about the differences in the results of action according to gender.

Research needs to be done by coping skills training for moderate to severe anxiety with longer time periods and more consistent responders to get therapy from beginning to the end.

\section{Acknowledgement}

The researcher would like to thank the respondents who have took part following this research, especially to Directorate of Research and Development in Society (DRPM) that supported to fund this research, Nursing Faculty Universitas Indonesia.

\section{References}

[1] Aust, H., Rüsch, D., Schuster, M., Sturm, T., Brehm, F., \& Nestoriuc, Y. (2016). Coping strategies in anxious surgical patients. BMC Health Services Research, 16, 250 https://doi.org/10.1186/s12913016-1492-5.

[2] Badan Narkotika Nasional. (2015). Press Release Akhir Tahun 2015, 44.

[3] Badr, L. K., Taha, A., \& Dee, V. (2014). Substance Abuse in Middle Eastern Adolescents Living in Two Different Countries: Spiritual, Cultural, Family and Personal Factors. Journal of Religion and Health, 53(4), 1060-1074. https://doi.org/10.1007/s10943-0139694-1.

[4] Crandell, T., Crandell, C., Zanden, J.V. (2012). Human Development. Tenth Edition. New York: McGraw-Hill.

[5] Gilligan, R. B. E. T. (2008). Promoting Resilience. London: CoramBAAF. Retrieved from http://www.ebrary.com.

[6] Lebowitz, E. R., \& Omer, H. (2013). Treating childhood and adolescent anxiety. Retrieved from https://doi.org/10.1002/9781118589366.

[7] Sadock \& Sadock. (2015). Buku Ajar Psikiatri Klinis Edisi 2 (Profitasari dan Tiara Mahatmi Nisa, Penerjemah). Jakarta: EGC.

[8] Sellakumar, G. K. (2015). EFFECT OF SLOW-DEEP BREATHING EXERCISE TO REDUCE ANXIETY AMONG ADOLESCENT SCHOOL STUDENTS IN A SELECTED HIGHER SECONDARY, 23(1), 54-72.

[9] Stuart, Keliat \& Pasaribu. (2016). Prinsip dan Praktik Keperawatan Kesehatan Jiwa Stuart Edisi Indonesia. Jakarta: Elsevier.

[10] United Nations Office on Drugs and Crime. (2016). World Drug Report. United Nations Publication.

[11] World Health Organtization. (2017). Helath Education. Retrieved from http://www.who.int/topics/health_education/en/.

[12] Wu, C. S. T., Wong, H. T., Shek, C. H. M., \& Loke, A. Y. (2014). Multi-dimensional self-esteem and substance use among Chinese adolescents. Substance Abuse Treatment, Prevention, and Policy Vol 9 Oct 2014, ArtID 42, 9(1), 1-8. https://doi.org/10.1186/1747-597X9-42.

[13] Vancampfort, D., Hert, M. De, Knapen, J., Maurissen, K., Raepsaet, J., Deckx, S. Probst, M. (2011). Effects of progressive muscle relaxation on state anxiety and subjective well-being in people with schizophrenia : a randomized controlled trial https://doi.org/10.1177/0269215510395633.

[14] Videbeck, S.L. (2008). Buku Ajar Keperawatan Jiwa (Renata Komalasari dan Afrina Hany, Penerjemah). Jakarta: Penerbit Buku Kedokteran EGC. 